\title{
Digital knowledge improvement for Indonesian small and medium enterprises: Cultural change in digital mental
}

\author{
I. Wirasari \\ Telkom University, Bandung, Indonesia
}

\begin{abstract}
Cultural changes in society affect many areas of life, including the business sector as well as small and medium enterprises. During a pandemic, there are changes in the way people think, act, and socialize. The COVID-19 pandemic has altered the world's economic order to such a large degree that the International Monetary Fund predicted negative global economic growth in 2020. In Indonesia, economic activities have decreased drastically, especially with the governmentmandated, large-scale social restrictions and health protocols such as the use of masks and social distancing. The first strategy for Indonesian small- and medium-scale enterprises in the new normal is to conduct marketing research on consumers to meet their needs. Marketing research is part of the STP (segmentation, targeting, and positioning) marketing strategy, and is more suitable and appropriate to meet consumer needs. Although qualitative research methods and analyzing branding strategies were used, the current study analyzed how community, especially small business actors, adapts to this pandemic. Mental changes in society were analyzed as well as cultural changes in society's digital mental state. The results of the study showed mental changes along with the development of digitalization in all sectors.
\end{abstract}

Keywords: Cultural changes, digitalization, small and medium enterprises

\section{INTRODUCTION}

Reviewing the data from the Ministry of Cooperatives and small- and medium-scale enterprises (SMEs) of the Republic of Indonesia, micro, small, and medium enterprises (MSMEs) have experienced good development and growth over the years. In 2010, the total number of MSME units was $52,769,426$. In the latest news in early 2020, that number has reached 63 million. In a pandemic such as the COVID-19 we are experiencing now, SMEs are competing to be able to maintain their business.

The first strategy for new normal SMEs is to conduct marketing research to all consumers to meet their needs. Marketing research is part of the STP (segmentation, targeting, and positioning) marketing strategy. By conducting marketing research, this type of strategy is more suitable and appropriate to meet consumer needs.

The development of SMEs in Indonesia demonstrates a good pattern. The existence of support from the government in certain ways affects the growth rate of the number of micro, small, and medium enterprises. The use of technology and communication facilities, the allocation of business credits, and the reduction in the Final Income Tax rate, are several factors that encourage the development of SMEs in Indonesia. Even so, this growth is still considered slow because several supporting factors are considered not very effective.

These factors include the media for promotion and branding. SMEs' actors, who originally carried out promotions and branding with conventional media, are now starting to switch to digital media. The transition to digital media is a mental change that business owners must accept. However, this is not easy because the mental changes involved in going from conventional to digital means, including behavior changes that relate to cultural changes, must be adapted by SMEs. Subsequent 
social changes exist in changes that are fundamental or only complete previous changes. As an example, a change in the promotion media in Indonesia is the nature of completing previous deficiencies.

Based on the information above, the research problems were identified as follows.

(1) SMEs are still adapting conventional branding and promotion patterns.

(2) Changes from conventional media promotion and branding require an overall change in the mentality of business actors.

(3) A branding strategy is needed to support mental change in the way of thinking from conventional media to digital. Thus, the problems are the appropriate digital branding strategy for SMEs in Indonesia and how it affects the mental change of business actors.

\section{RESEARCH METHODOLOGY}

Bogdan \& Taylor (1975) in Moleong (2007) stated that qualitative methodology is a research procedure that produces descriptive data in the form of written or oral words from people as well as their observable behavior. Qualitative research aims at obtaining the complete picture of a matter according to the human point of view studied. Qualitative research is related to the ideas, perceptions, opinions, or beliefs of the people being studied.

\section{LITERATURE REVIEW}

Brand values/core ideas communicated to an audience have different weights and pressures depending on the characteristics of the product. Luxury and signature products place emphasis on the products themselves. Retail/culinary emphasize the ambience/atmosphere of an interior retail space. Service in general emphasizes behavior/attitude/hospitality of the business actors. Consumer goods emphasizes frequent communication through various media (Ollins, 2008).

Based on Ollins (2008), there are the four vectors through which a brand emerges. They are product, behavior, environment, and communication. The four vectors are interrelated in changing the knowledge of businesspeople from conventional thinking to digital, both for branding and promotion purposes. Brand management should be treated as a resource in every way equal to financial management or IT management, as a corporate resource which will work effectively when it embraces every part of the organization (Ollins, 2008).

\section{DISCUSSION AND RESULT}

\subsection{Small and medium business branding strategy in the new normal}

Before creating a branding strategy for SMEs, a mapping is needed. Things that must be mapped and analyzed are as follows.

(1) Marketing Research. The first strategy for the new normal SMEs is to conduct marketing research or research to all consumers in order to meet consumers' needs. Marketing research is part of the STP marketing strategy. By conducting marketing research, you can discover which strategy is more suitable and appropriate to meet consumer needs.

(2) Product Portfolio Evaluation. The strategy for the next new normal SME is to evaluate the products that will appear when entering the new normal era, where consumers will be more careful about using new products even at very economical prices. There is even a possibility that consumers will instead use cheaper products with standard quality because consumers tend to be cautious and aware that the crisis will recur.

(3) Evaluate Prices and Pay Attention to Competitors. Evaluate the problem of price because consumers tend to reduce their purchasing power to be more careful about buying and 


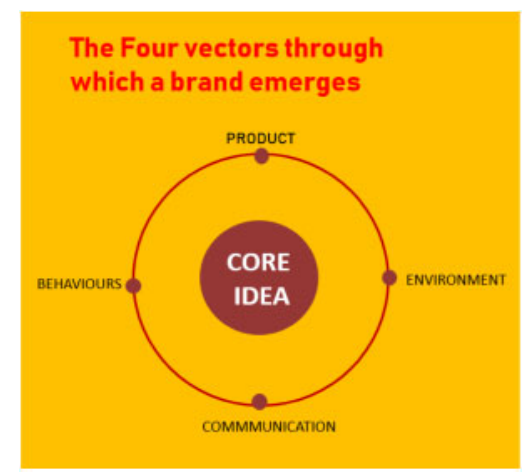

Figure 1. The four vectors through which a brand emerges. Source: Ollins (2008).

consuming. To neutralize the decline in the purchasing power of consumers, MSMEs must have more creativity in determining economical packages or promotional packages that are attractive to consumers, e.g., product packaging. SMEs can do promotional packages by providing 3-in-1 packages or cheaper price selling products with smaller packages. Another sales strategy is to offer wholesale prices to consumers given the trend of group buying or panic buying. Such strategies make consumers choose SME products over competing products.

(4) Focus sales on the online channel. The last new normal SME strategy is to focus on online business, considering that this new normal era has forced the switch to online channels due to changes in consumer behavior. Moreover, with the condition of the COVID-19 virus outbreak, mobilization is limited and social distancing is encourged, so that consumers look for products through the marketplace. To take advantage of this change in consumer behavior by shifting sales focus to online channels, one must be aggressive in launching selling on websites, social media, and e-commerce.

Based on the results of the mapping above, it can be concluded that there are three important components in a branding strategy, namely, content and database advertisement. In terms of content, SMEs must be able to create content that is attractive and in accordance with the target market. Taking advantage of what is currently popular can also increase audience engagement with the content. SMEs must also collect and analyze databases because it serves to maximize promos to the right audience. Furthermore, ads for promotion must also be done because they are useful for expanding the achievement of content created digitally to new users outside the database that are still in accordance with the target market. Various types of digital marketing tactics and strategies basically have the same goal: to promote a product or service to increase brand awareness which in turn increases the number of purchases.

\subsection{Collaboration}

In addition, it is important for MSME actors to collaborate with various parties to be able to move more quickly and effectively. In increasing the SME business, Jalur Nugraha Ekakurir is now launching COD (Cash On Delivery) Retail feature, a service product to facilitate online buying and selling activities through cash transaction on product delivery time. This is designed to make it easier for people to buy necessities online and to encourage SMEs to continue to grow in the midst of the COVID-19 pandemic in the face of the new normal.

\subsection{Soft selling}

Soft selling is when you adverstise a new product by releasing a product teaser that contains product knowledge, prices, and launch dates. A timeline is then created to address pre-orders and such. 


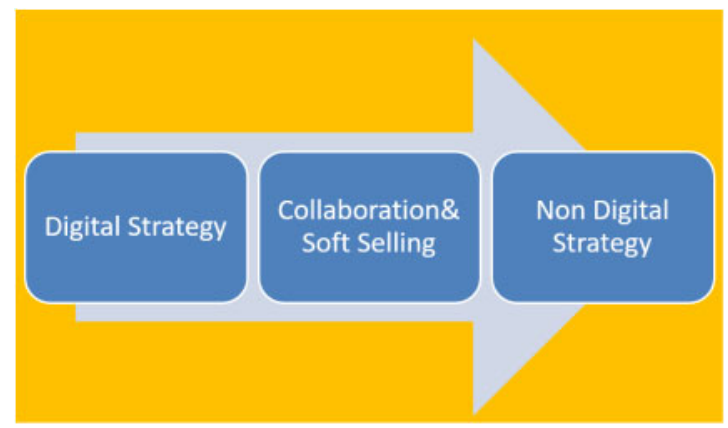

Figure 2. Branding strategy flow.

\section{Scheme of Cultural Change from Conventional to Digital}

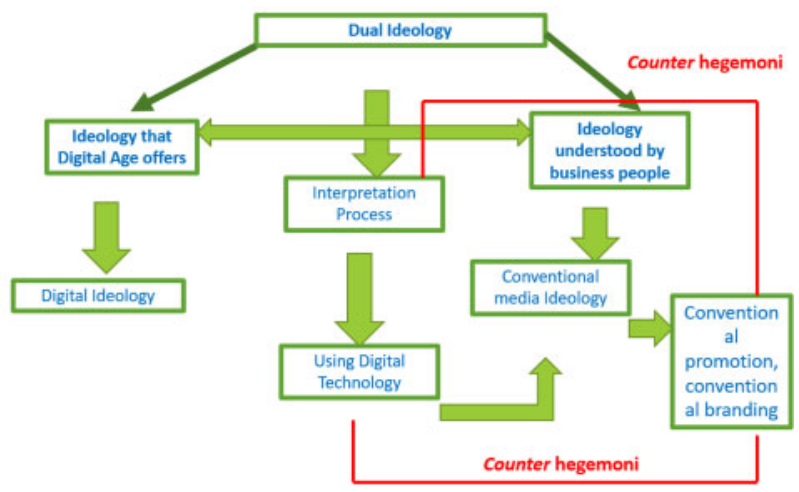

Figure 3. Scheme of cultural change.

\subsection{Non digital strategy}

Expand Sales Territory. SMEs depend on customers and employees from one region. Today, this is very risky as the COVID-19 crisis in the red zone could stop a company's sales and operations. It is important, then, that SMEs diversify their location to minimize disruption and maintain income.

Increase knowledge about business. For SMEs, new technology has made it easier to expand their local footprint and even go global. For example, to handle customers and fulfill orders, an add-on for an e-commerce platform can translate a retail website into multiple languages and help ship products around the world.

\subsection{Mental change to the digital age}

Associated with the theory of cultural politics, branding and promotion have actually become desirable for business actors, both large, medium, and small. It can be said that this desire is a reference for the expectations of the business actor. Within that desire are elements of digital branding and promotion. These elements form a culture in society, and within the elements there are certain goals of the ruling class regarding carrying out their ideas to society.

Based on the description above, those in the ruling class must compete with one another so that the culture offered by them is accepted by the community. It can be concluded that the battle for the power of media branding and promotion is not just a power struggle between conventional and digital media, but is broader than that, namely a battle of ideology. 
In truth, there are many businesses disappearing of which we are not aware. These businesses are reluctant to adapt to the changing era because they are too comfortable with the glory they have achieved in the past. Apart from being too comfortable, there are also some businesses that don't know how to deal with this digital transformation. They were stunned to see new start-ups popping up and grabbing their customers, one after another.

There are some businesses that have adapted successfully and others that keep trying but still fail. The successful transformation of a business, organization, or company is not determined by one person. In fact, digital transformation requires all parties in an organization to adapt. Skills such as the ability to take advantage of technology to simplify and speed up work are essential for helping a business adapt to the digital era.

\section{REFERENCES}

Bogdan dan Taylor. 1975. Metodologi Penelitian Kualitatif. Remadja Karya, Bandung.

Moleong, Lexy J. 2007. Metodologi Penelitian Kualitatif. Edisi Revisi. PT Remaja Rosdakarya, Bandung.

Shimp, Terence, A. 2003. Periklanan Promosi dan Aspek Tambahan Komunikasi Pemasaran Terpadu, Jilid 1 (edisi 5), Jakarta: Erlangga.

Lee, Monle \& Carla Johnson. 2013. Principles of Advertising, A Global Perspective, Second Edition, Routledge, England.

Morissan, M.A. 2010. Periklanan Komunikasi Pemasaran Terpadu, Kencana, Jakarta.

Olins, Wally, 2008. The Brand Handbook, Thames \& Hudson, England.

Olins, Wally, 2014. Brand New, The Shape of Brands to Come, Thames \& Hudson, England.

Sugiyono. 2018. Metode Penelitian Kualitatif, Bandung: Alfabeta. 


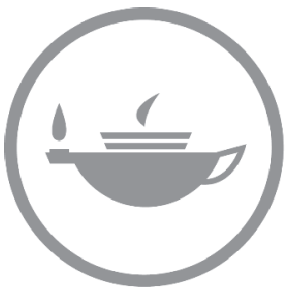

Taylor \& Francis Taylor \& Francis Group

http://taylorandfrancis.com 